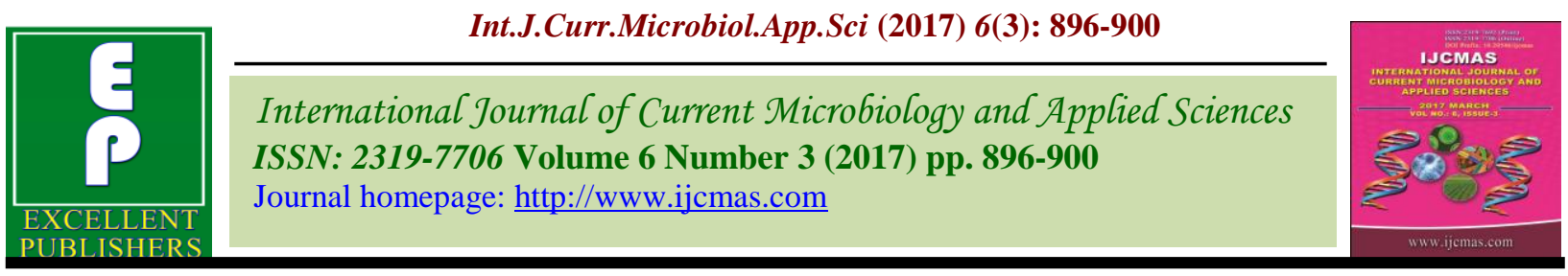

Original Research Article

https://doi.org/10.20546/ijcmas.2017.603.105

\title{
Effect of Non-Genetic Factors on Reproductive Performance of Nellore Brown Sheep
}

\author{
D. Vishnu Vardhan Reddy ${ }^{1}$, D. Sreenivas ${ }^{2}$, M. Gnanaprakash ${ }^{3}$, Ch. Harikrishna $^{4}$ \\ ${ }^{1}$ Department of Animal Genetics and Breeding, College of Veterinary Science, SVVU, \\ Proddatur, Kadapa district, Andhrapradesh-516360, India \\ ${ }^{2}$ Department of Animal Genetics and Breeding, College of Veterinary Science, P.V. Narsimha \\ Rao Telangana Veterinary University, Korutla, Karimnagar, Telangana-505326, India \\ ${ }^{3}$ Poultry Research Station, College of Veterinary Science, P.V. Narsimha Rao \\ TelanganaVeterinary University, Rajendranagar, Hyderabad-500030, India \\ ${ }^{4}$ Livestock Research Station, P.V. Narsimha Rao TelanganaVeterinary University, Mamnoor, \\ Warangal, Telangana - 506166, India \\ *Corresponding author
}

\begin{tabular}{|c|c|}
\hline & A B S T R A C T \\
\hline $\begin{array}{l}\text { Ke y w o r d s } \\
\text { Nellore Brown, } \\
\text { Reproductive traits, } \\
\text { Non-genetic factors, } \\
\text { sheep. }\end{array}$ & \multirow{3}{*}{$\begin{array}{l}\text { The data on reproductive performance of } 502 \text { Nellore Brown lambs born during } 2006 \text { to } \\
2011 \text { maintained at Livestock Research Station, Mamnoor, Warangal district which is a } \\
\text { constituent of Sri P.V. Narsimha Rao Telangana Veterinary University, Hyderabad, were } \\
\text { utilized for the present study. The overall least squares mean age at first service(AFS), age } \\
\text { at first lambing (AFL), service period (SP) and lambing interval (LI) were } 593.55 \pm 6.74 \text {, } \\
742.53 \pm 6.75,155.03 \pm 10.71 \text { and } 304.41 \pm 10.71 \text { days, respectively. Year of birth had } \\
\text { shown highly significant }(\mathrm{P} \leq 0.01) \text { effect on all the reproductive traits studied. The season } \\
\text { of birth significantly ( } \leq 0.01) \text { influenced service period and lambing interval only. The } \\
\text { parity of the ewe had significant ( } \mathrm{P} \leq 0.05) \text { effect on service period and lambing interval. } \\
\text { The significant effect of non-genetic factors plays an important role in reproductive } \\
\text { performance of animal so higher emphasis on management practices, nutrition and health } \\
\text { cover will improve the reproductive performance of animal. }\end{array}$} \\
\hline Article Info & \\
\hline $\begin{array}{l}\text { Accepted: } \\
18 \text { February } 2017 \\
\text { Available Online: } \\
10 \text { March } 2017\end{array}$ & \\
\hline
\end{tabular}

\section{Introduction}

Small ruminants have become the most promising livestock in the country due to ample marketing opportunities for their products. Sheep farming is a major source of income and livelihood of small and marginal farmers of arid and semi-arid regions of India besides providing nutritional security to the rural people. Sheep are efficient converters of unutilized poor quality grass and crop residues into meat and skin. However, the performance of different breeds of sheep in
India is relatively low as they are reared mostly under harsh and unfavorable climatic conditions (Arora and Garg, 1998). Most of the south Indian breeds are mainly maintained for meat production. Mutton is one kind of meat towards, which there is no prejudice by any community in India and further development of superior breeds for mutton production will have a great scope in the developing economy of India. The role of sheep is more pronounced as a source of non- 
vegetarian food. Further, the demand for nonvegetarian food products is on increase and its consumption would be nearly 8.0-9.0 million tons by 2020, up from 2.0-3.0 million tons in 2001 (Birthal and Taneja, 2006). To meet the surging domestic and international demand for mutton and mutton products, it is necessary to improve the production and productivity of sheep.

Nellore is a popular and tallest mutton breed in the country distributed predominantly in Nellore and Prakasam districts of Andhra Pradesh. Nellore is also known for heat tolerance, disease resistance and thrives well in harsh conditions. Based on coat color pattern Nellore sheep is classified into three varieties viz. Palla, Jodipi and Brown or Dora. There is no information available on the reproductive performance of Nellore Brown sheep. Therefore present study was under taken to study the effect of non-genetic factors on the reproductive performance of Nellore Brown sheep under organized farm conditions to find out the breeding and management interventions for improvement in economically important traits.

\section{Materials and Methods}

The data on reproductive performance of 502 Nellore Brown lambs born during 2006 to 2011 maintained at Livestock Research Station, Mamnoor, Warangal district which is a constituent of Sri P.V. Narsimha Rao Telangana Veterinary University, Hyderabad, were utilized for the present study. The animals were maintained on semi-intensive system with a provision of concentrates supplementation (250-300g/day/animal) and 8hours grazing. Water is provided ad libitum in the farm and grazing areas. Lambs were weaned at the age of 3 months. Data on age at first service, age at first lambing, service period and laming interval were analysed by using the least squares analysis of variance technique using mixed model least-squares and maximum likelihood computer program pc-2 developed by Harvey (1990). The linear model included the effect of factors like year of birth, season of birth (major-October to December, off-season-April to June) and parity as fixed effects. Duncan's Multiple Range Test (D.M.R.T) as modified by Kramer (1957) was used for comparing the sub-group means.

\section{Results and Discussion}

\section{Age at First Service}

The overall least squares mean age at first service was $593.55 \pm 6.74$ days (Table 1) and the means recorded in the present study are close to means reported by Dixit et al., (2002) in Bharat Merino sheep (580 \pm 13days), Gopaldass et al., (2004) in Marwari sheep (579.27 \pm 2.24 days) and Rajanna et al., (2012) in Nellore sheep (610.00 \pm 3.81 days). However, higher age at first service was reported in Nellore sheep (779.88 \pm 16.35 days) by Gupta et al., (1987), in Nali ewes (775.83 \pm 12.94days) by Dey and Poonia (2005) whereas lower age at first service was reported by Mane et al., (2014) in Deccani sheep (489.21 \pm 3.55 days). The variation may due to breed differences in breeds, agroclimatic conditions and feeding management.

The data analysis revealed that the effect of year of birth was significant $(\mathrm{P} \leq 0.01)$ on the age at first service. Similar findings were reported by Dixit et al., (2002) in Bharat Merino sheep and Mandakmale et al., (2013) in Deccani sheep while contrasting results were reported by Mane et al., (2014) in Deccani sheep. The mean age at first service among the years ranged from $526.23 \pm 18.17$ (2011) to $732.18 \pm 14.14$ days (2006) which might be due to better body condition of ewes due to higher growth rates during early stages of life. 
The least squares analysis of variance revealed that there is no significant difference between the lambs born during off season $(594.75 \pm 10.07)$ and main season (592.35 \pm 8.05 days). Similar findings were observed by Mane et al., (2014) in Deccani sheep while contrasting findings were reported by Dixit et $a l .$, (2002) in Bharat Merino sheep, Dey and Poonia (2005) in Nali sheep and Mandakmale et al., (2013) in Deccani sheep.

\section{Age at First lambing}

The overall least squares mean age at first lambing was $742.53 \pm 6.75$ days (Table 1). The present findings are close to the mean AFL reported in Bharat Merino sheep (730 \pm 13 days) by Dixit et al., (2002) and in Marwari sheep $(730.50 \pm 2.47$ days $)$ by Gopaldass et al., (2004). Higher AFL was reported Acharya (1982) in Nellore sheep (841.04 \pm 1.21days) and Dey and Poonia (2005) in Nali sheep (925.08 \pm 13.02 days) whereas lower means were reported by Poonia (2008) in Munjal sheep (530.53 \pm 12.39 days) and Mane et al., (2014) in Deccani sheep (638.91 \pm 3.56 days).The variation may due to breed differences in breeds, agro-climatic conditions and feeding management.

The least squares analysis of variance revealed significant $(\mathrm{P} \leq 0.01)$ effect of year of birth on age at first lambing. Similar findings were observed by Dixit et al., (2002) in Bharat Merino sheep and Mandakmale et al., (2013) in Deccani sheep whereas nonsignificant effect of year of birth was reported by Mane et al., (2014) in Deccani sheep. Mean AFL ranged from $675.68 \pm 18.19$ (2011) to $881.11 \pm 14.15$ days (2006) which might be due to better body condition of ewes due to higher growth rate during early age.

The effect of season of birth was nonsignificant on the age at first lambing. Similar findings were reported by Mane et al., (2014) in Deccani sheep and the significant effect of season of birth was reported in Bharat Merino sheep by Dixit et al., (2002), in Nali sheep by Dey and Poonia (2005) and in Deccani sheep by Mandakmale et al., (2013).The mean age at first lambing for the lambs born during off season and main season were $743.71 \pm 10.08$ and $741.35 \pm 8.06$ days, respectively.

\section{Service period}

The overall least squares mean service period was $155.03 \pm 10.71$ days (Table 1 ) and the estimate is close to the mean value reported by Dixit et al., (2002) in Bharat Merino sheep (142 \pm 26 days) and lower mean was reported by Patro et al., (2006) in indigenous meat type sheep of coastal Orissa $(63.13 \pm 0.25$ days).

The analysis of data revealed the significant $(\mathrm{P} \leq 0.01)$ effect of year of birth on service period and ranged from 104.10 \pm 16.84 (2008) to $288.83 \pm 15.05$ days (2006) which might be due to better body condition of ewes due to higher growth rates in early stages of life. The effect of season of birth was significant $(\mathrm{P} \leq 0.01)$ on service period and the lambs born during offseason (178.62 \pm 13.23$)$ had higher service period than the lambs born during main season (131.44 \pm 12.18 days), which might be due to better availability of fodder and management practices in farm. The data analysis revealed, the parity of ewes significantly $(\mathrm{P} \leq 0.05)$ contributed to the variation in service period and similar findings were reported by Dixit et al., (2002) in Bharat Merino sheep. Service period reduced from first parity $(174.55 \pm 7.95)$ to the second parity $(135.51 \pm 18.33)$.

\section{Lambing interval}

The overall least squares mean lambing interval was $304.41 \pm 10.71$ days (Table 1). The means recorded in the present study are in accordance with the findings of Dixit et al., 
(2002) in Bharat Merino sheep (290 \pm 26 days), Mane et al., (2014) in Deccani sheep $(307.90 \pm 1.37$ days). However higher lambing interval was reported by Rajanna et al., (2012) in Nellore sheep $(420.93 \pm 2.76$ days) and lower values reported by Patro et al., (2006) in indigenous meat type sheep of coastal Orissa (214.01 \pm 0.33 days).

Table.1 Least-squares means $( \pm \mathrm{SE})$ for reproductive traits (days) in Nellore brown sheep

\begin{tabular}{|c|c|c|c|c|}
\hline Effects & AFC & AFL & SP & LI \\
\hline Overall mean & $\begin{array}{c}593.55 \pm 6.74 \\
(502)\end{array}$ & $\begin{array}{c}742.53 \pm 6.75 \\
(502)\end{array}$ & $\begin{array}{c}155.03 \pm 10.71 \\
(571)\end{array}$ & $\begin{array}{c}304.41 \pm 10.71 \\
(571)\end{array}$ \\
\hline Year & $* *$ & $* *$ & $* *$ & $* *$ \\
\hline 2006 & $\begin{array}{c}732.18^{\mathrm{a}} \pm 14.14 \\
(83)\end{array}$ & $\begin{array}{c}881.11^{\mathrm{a}} \pm 14.15 \\
(83)\end{array}$ & $\begin{array}{c}288.83^{\mathrm{a}} \pm 15.05 \\
(114)\end{array}$ & $\begin{array}{c}437.99^{\mathrm{a}} \pm 15.06 \\
(114)\end{array}$ \\
\hline 2007 & $\begin{array}{c}591.41^{\mathrm{b}} \pm 7.92 \\
(222)\end{array}$ & $\begin{array}{c}740.25^{\mathrm{b}} \pm 7.93 \\
(222)\end{array}$ & $\begin{array}{c}163.85^{\mathrm{b}} \pm 11.16 \\
(252)\end{array}$ & $\begin{array}{c}313.03^{\mathrm{b}} \pm 11.17 \\
(252)\end{array}$ \\
\hline 2008 & $\begin{array}{c}591.51^{\mathrm{b}} \pm 12.64 \\
(91)\end{array}$ & $\begin{array}{c}740.23^{\mathrm{b}} \pm 12.66 \\
(91)\end{array}$ & $\begin{array}{c}104.10^{\mathrm{d}} \pm 16.84 \\
(96)\end{array}$ & $\begin{array}{c}253.33^{\mathrm{d}} \pm 16.85 \\
(96)\end{array}$ \\
\hline 2009 & $\begin{array}{c}589.62^{\mathrm{b}} \pm 22.34 \\
\text { (27) }\end{array}$ & $\begin{array}{c}738.20^{\mathrm{b}} \pm 22.37 \\
(27)\end{array}$ & $\begin{array}{c}132.62^{\mathrm{c}} \pm 26.82 \\
(29)\end{array}$ & $\begin{array}{c}282.35^{\mathrm{c}} \pm 26.84 \\
(29)\end{array}$ \\
\hline 2010 & $\begin{array}{c}530.36^{\mathrm{c}} \pm 19.34 \\
\text { (36) }\end{array}$ & $\begin{array}{c}679.72^{c} \pm 19.36 \\
(36)\end{array}$ & $\begin{array}{c}110.09^{\mathrm{d}} \pm 24.31 \\
(37)\end{array}$ & $\begin{array}{c}259.60^{\mathrm{d}} \pm 24.32 \\
(37)\end{array}$ \\
\hline 2011 & $\begin{array}{c}526.23^{\mathrm{c}} \pm 18.17 \\
\text { (43) }\end{array}$ & $\begin{array}{c}675.68^{\mathrm{c}} \pm 18.19 \\
(43)\end{array}$ & $\begin{array}{c}130.67^{\mathrm{c}} \pm 23.26 \\
(43)\end{array}$ & $\begin{array}{c}280.13^{\mathrm{c}} \pm 23.28 \\
(43)\end{array}$ \\
\hline Season & $\mathrm{NS}$ & $\mathrm{NS}$ & $* *$ & $* *$ \\
\hline $\begin{array}{l}\text { Off-season } \\
\text { (April-June) }\end{array}$ & $\begin{array}{c}594.75 \pm 10.07 \\
(193)\end{array}$ & $\begin{array}{c}743.71 \pm 10.08 \\
(193)\end{array}$ & $\begin{array}{c}178.62^{\mathrm{a}} \pm 13.23 \\
(218)\end{array}$ & $\begin{array}{c}328.03^{\mathrm{a}} \pm 13.24 \\
(218)\end{array}$ \\
\hline $\begin{array}{c}\text { Main season } \\
\text { (Oct- Dec) }\end{array}$ & $\begin{array}{c}592.35 \pm 8.05 \\
(309)\end{array}$ & $\begin{array}{c}741.35 \pm 8.06 \\
(309) \\
\end{array}$ & $\begin{array}{c}131.44^{\mathrm{b}} \pm 12.18 \\
(353)\end{array}$ & $\begin{array}{c}280.78^{\mathrm{b}} \pm 12.19 \\
(353)\end{array}$ \\
\hline Parity & & & $*$ & $*$ \\
\hline 1 & - & - & $\begin{array}{c}174.55^{\mathrm{a}} \pm 7.95 \\
(502)\end{array}$ & $\begin{array}{c}323.72^{\mathrm{a}} \pm 7.95 \\
(502)\end{array}$ \\
\hline 2 & - & - & $\begin{array}{c}135.51^{\mathrm{b}} \pm 18.33 \\
(69)\end{array}$ & $\begin{array}{c}285.09^{\mathrm{b}} \pm 18.34 \\
(69)\end{array}$ \\
\hline
\end{tabular}

Figures in parentheses are number of observations; ${ }^{*}$ Significant $(\mathrm{P} \leq 0.05) ;{ }^{* *}$ Significant $(\mathrm{P} \leq 0.01)$; NS-Non Significant; Means followed by the same super script(s) do not differ significantly $(\mathrm{P} \leq 0.05)$

In the present study, effect of year on lambing interval was significant $(\mathrm{P} \leq 0.01)$ and similar findings reported by Mane et al., (2014) in Deccani sheep and contrast findings were reported by Dey and Poonia (2005) in Nali sheep and Mandakmale et al., (2013) in Deccani sheep. Lambing interval ranged from $253.33 \pm 16.85$ (2008) to $437.99 \pm 15.06$ days (2006).The lambing interval was significantly
$(\mathrm{P} \leq 0.01)$ higher in lambs born during off season $(328.03 \pm 13.24)$ than the main season $(280.78 \pm 12.19$ days) whereas, nonsignificant effect of season of birth reported in Nali sheep by Dey and Poonia (2005) and in Deccani sheep Mandakmale et al., (2013). Parity of the ewes had significant $(\mathrm{P} \leq 0.05)$ effect on lambing interval and similar findings reported by Dixit et al., (2002) in 
Bharat Merino sheep. This difference might be due to the better physiological condition of the ewes in the second parity.

It can be concluded that non-genetic factors like year, season of birth and parity influenced the reproductive performance of Nellore Brown sheep due to variations in management, feed and fodder resources available during period so higher emphasis on management practices, nutrition and health cover will improve the reproductive performance of animal.

\section{Acknowledgements}

Thanks to Head of Livestock Research Station, P.V. Narsimha Rao Telangana Veterinary University, Mamnoor, Warangal, Telangana for permitting and providing necessary data for research work.

\section{References}

Acharya, R.M. 1982. Sheep and goat breeds of India.Food and Agriculture Organization of the United Nations.

Arora, C.L., and Garg, R.C. 1998. Sheep production and breeding, International Book Distributing Company.

Birthal, P.S., Taneja, V.K. and Thorpe, W. 2006. Smallholder livestock production in India Opportunities and challenges: Proceedings of an ICAR-ILRI international workshop, New Delhi, India, 31 January-1 February 2006. Nairobi: ILRI and NCAP.

Dass, G., Singh, V.K., Mehta, S.C., and Sharma, P.R. 2004. Reproductive traits of Marwari sheep in arid Rajasthan. The Indian J. Small Ruminants, 10(1): 88-89.

Dey, B., and Poonia, J.S. 2005. Reproductive performance of Nali sheep. Indian J. Small
Ruminants, 11(1): 10-13.

Dixit, S.P., Dhillon, J.S., and Singh, G. 2002.Sources of variation in reproductive traits of 7.Bharat Merino sheep. Indian J. Animal Sci., 72(4): 328-331.

Gupta, B.R., Reddy, K.K., and Munirathnam, D. 1987. Puberty and sexual maturity in Nellore 9. Sheep and its synthetics with Dorset. Short communication, Indian J. Animal Sci., 57(9): 1013-1016.

Harvey, W.R. 1990. User's Guide for LSMLMW and MIXMDL PC-2 version. Mixed model least-squares and maximum likelihood computer program, Ohio State University, Columbus, Ohio, USA.

Kramer, C.Y. 1957. Extension of multiple range tests to group correlated adjusted means. Biometrics, 13(1): 13-18.

Mandakmale, S.D., Birari, D.R., Shinde, S.D., and Sakhare, P.S. 2013. Effect of non-genetic factors on reproductive performance of sangamneri strain of deccani sheep. Indian J. Small Ruminants, 19(1): 83-84.

Mane, P.M., Pachpute, S.T., and Nimase, R.G. 2014.Growth and reproductive performance of Deccani sheep in an organised farm. Indian J. Small Ruminants, 20(2): 2327

Patro, B.N., Mallick, C.R., Rao, P.K., and Panda, P. 2006. Production performance of indigenous meat type sheep in Kendrapada Distirct of coastal Orissa. Indian J. Small Ruminants, 12(1): 42-47.

Poonia, J.S. 2008. Reproductive performance of Munjal sheep. The Indian J. Small Ruminants, 14(1): 121-123.

Rajanna, N., Mahendar, M., Raghunandan, T., Sreenivasarao, D., Nagalakshmi, D., and Thammiraju, D. 2012. Reproductive performance of Nellore sheep in different agroclimatic zones of Telangana. Animal Sci. Reporter, 6(4): 142-145.

\section{How to cite this article:}

Vishnu Vardhan Reddy, D., D. Sreenivas, M. Gnanaprakash and Harikrishna, Ch. 2017. Effect of Non-Genetic Factors on Reproductive Performance of Nellore Brown Sheep. Int.J.Curr.Microbiol.App.Sci. 6(3): 896-900. doi: https://doi.org/10.20546/ijcmas.2017.603.105 